\title{
The experience of using GRI Standards in sustainable development reports by Russian industrial corporations
}

\author{
Vera Samarina ${ }^{1, *}$, Tatiana Skufina ${ }^{1}$, and Aleksandr Samarin ${ }^{2}$ \\ ${ }^{1}$ Luzin Institute for Economic Studies, Federal Research Centre «Kola Science Centre of the Russian \\ Academy of Sciences», Fersman Str., 14, 184209 Apatity, Russia \\ ${ }^{2}$ Belgorod State National Research University (Staryy Oskol Branch), Solnechny Str., 18, 309502 \\ Staryy Oskol, Russia
}

\begin{abstract}
Some moments in the history of the formation of the concept and the modern components of the mechanism of industrial corporations sustainable development, which comprehensively combines the managerial, economic, social and environmental aspects have been presented in the paper. The experience of disclosing information in the field of sustainable development by the largest metallurgical corporations having assets in the Russian Federation has been presented and analyzed as well. The research has shown that using the unified GRI Standards recommendations, management of each corporation independently determines the number and composition of indices required to assess the Triple Bottom Line. It has been concluded that the lack of a unified methodology for disclosing information in the field of achieving sustainable development results does not allow corporations to compare them, since one of the main principles of scientific research, i.e. the principle of results comparability is violated. The following authors' position is defended: in order to eliminate the reasons that complicate the comparative assessment of the results of sustainable development of industrial corporations, the reporting methodology needs to be improved.
\end{abstract}

\section{Introduction}

Russian business in the post-Soviet space has begun to form relatively recently. Moreover, in the practice of managing Russian enterprises, the experience of developed and developing countries in the field of enterprise management is actively used. Russian industry in real sectors of the economy is quite attractive for foreign capital. Therefore, many processes of the formation and development of business structures in the Russian industry proceed at a growing rate. In the context of globalization of the world economy, the importance of large industrial corporations is growing. They affect the economy, ecology, society, often determining the vector and level of socio-economic development of the regions of presence. This is noted by many Russian researchers [1-3].

\footnotetext{
*Corresponding author: samarina_vp@mail.ru
} 
In this regard, we consider it important that more and more Russian enterprises are joining the concept of sustainable development. In our research, we noted that Russian metallurgical corporations, among other large industrial associations, begin to supplement their annual reports concerning production and financial achievements with reports on sustainable development, in which they present social and environmental achievements [4$6]$.

Despite the significant interest of scientists in the concept of sustainable development and the active work of corporations in the practical implementation of this concept in practice, there is not only common methods, but a unified methodology for reporting on the results of sustainable development as well. Moreover, this situation has developed not only in Russia, but also in world practice [7-9]. All this makes the presented research actual.

The purpose of the research is to consider the experience of using GRI Standards in reports concerning the sustainable development of corporations having industrial assets in the Russian Federation.

To achieve this goal, the following tasks have been solved:

- some moments in the history of the concept formation and modern components of the mechanism of sustainable development of industrial corporations have been presented;

- the experience of disclosing information in the field of sustainable development of metallurgical corporations having assets in the Russian Federation has been presented and analyzed.

\section{Materials and Methods}

The methodological concept of the research is a frame of reference based on a systematic approach. This made it possible to consider industrial corporations as complex, dynamic open economic systems that have a goal orientation and an organizing principle.

Several largest industrial corporations of ferrous metallurgy with production facilities in the Russian Federation became the specific object of the research (Table 1).

Table 1. The largest corporations of ferrous metallurgy having industrial capacities in Russia

\begin{tabular}{|c|c|c|c|c|c|}
\hline \multirow[b]{2}{*}{ Corporation } & \multirow[b]{2}{*}{ Geography } & \multicolumn{2}{|c|}{ Industrial capacities in Russia } & \multirow[b]{2}{*}{$\begin{array}{l}\text { EBITDA, } \\
\text { millon, \$ }\end{array}$} & \multirow{2}{*}{$\begin{array}{c}\text { EBITD } \\
\mathbf{A} \\
\text { margin, } \\
\%\end{array}$} \\
\hline & & Mining enterprises & $\begin{array}{c}\text { Metallurgical } \\
\text { enterprises }\end{array}$ & & \\
\hline $\begin{array}{l}\text { EVRAZ } \\
\text { Group }\end{array}$ & $\begin{array}{c}\text { Russia, } \\
\text { Kazakhstan, } \\
\text { Ukraine, } \\
\text { Czech } \\
\text { Republic, } \\
\text { Italy, Canada, } \\
\text { USA, } \\
\text { South Africa }\end{array}$ & $\begin{array}{c}\text { EVRAZ Kachkanar } \\
\text { Mining and } \\
\text { Processing Plant } \\
\text { JSC } \\
\text { EVRAZ West } \\
\text { Siberian } \\
\text { Metallurgical Plan } \\
\text { JSC } \\
\end{array}$ & $\begin{array}{c}\text { Nizhny Tagil } \\
\text { Metallurgical Plant } \\
\text { OJSC } \\
\text { EVRAZ United West } \\
\text { Siberian Metallurgical } \\
\text { Plant OJSC }\end{array}$ & 3777 & 29.0 \\
\hline $\begin{array}{l}\text { Severstal } \\
\text { PJSC }\end{array}$ & $\begin{array}{l}\text { Russia, } \\
\text { Spain, } \\
\text { USA }\end{array}$ & $\begin{array}{c}\text { Korelsky Okatysh } \\
\text { JSC } \\
\text { Olkon JSC } \\
\text { Yakovlevsky GOK } \\
\text { JSC } \\
\end{array}$ & $\begin{array}{c}\text { Cherepovets } \\
\text { Metallurgical Plant } \\
\text { JSC } \\
\text { Izhora Pipe Plant JSC } \\
\text { Severstal-Metiz JSC }\end{array}$ & 3142 & 36.6 \\
\hline $\begin{array}{l}\text { NLMK } \\
\text { Group }\end{array}$ & $\begin{array}{l}\text { Russia, } \\
\text { European } \\
\text { countries, } \\
\text { USA }\end{array}$ & $\begin{array}{c}\text { Stoilensky GOK } \\
\text { JSC }\end{array}$ & $\begin{array}{c}\text { Novolipetsk } \\
\text { Metallurgical Plant } \\
\text { JSC }\end{array}$ & 3589 & 30.0 \\
\hline $\begin{array}{c}\text { Metalloinves } \\
\mathrm{t}\end{array}$ & Russia & $\begin{array}{c}\text { Mikhailovsky GOK } \\
\text { PJSC } \\
\text { Lebedinsky GOK } \\
\text { JSC } \\
\end{array}$ & $\begin{array}{c}\text { Oskol } \\
\text { Electrometallurgical } \\
\text { Plant JSC }\end{array}$ & 2934 & 40.8 \\
\hline
\end{tabular}


The choice of these metallurgical corporations as an object of the research is explained by the fact that since 2018 they have been using the GRI Standards for drawing up of accounts of sustainability. All corporations include resource-supplying mining enterprises (GOKs) and metallurgical enterprises processing iron ore products. The EBITDA of each corporation is quite high and amounts to about $\$ 3$ billion or more. EBITDA margin indicates financial success and ranges from 29.0\% for EVRAZ Group to $29.0 \%$ for Metalloinvest.

The paper will analyze the experience of metallurgical corporations in presenting results in the field of sustainable development, which is based on the GRI Standards guideline developed by the international organization Global Reporting Initiative (GRI). This organization develops and promotes independent standards for assessing the activities of various organizations in such areas as anti-corruption, anti-competitive behavior, biodiversity, compliance with environmental requirements, etc. [10].

\section{Results and Discussion}

\subsection{The history of concept formation and modern components of the mechanism of sustainable development of industrial corporations}

The concept of sustainable development of large industrial corporations was formed on the basis of the concept of social responsibility of business. The founder of this concept is Howard Bowen, who examined the activities of large companies from the standpoint of responsibility to society in his monograph ("Social Responsibilities of the Businessman") in the middle of the last century [11]. H. Bowen expressed the opinion that the values of society should set vector of industrial development, and it was perceived by the scientific community with great interest.

However, there were opponents of this position as well. For example, Milton Friedman's paper "The social responsibility of business is to make a profit", published in 1970, is quite famous. The article, which laid the foundation for the theory of corporate egoism, maintains the stand that business as such should not be socially responsible, as long as the activities of corporations are always directed at making a maximum possible profit. A head of the company should show social responsibility [12]. Thus, social responsibility becomes personalized.

The principles of sustainable development of industrial corporations are in many ways similar to the principles of corporate social responsibility. However, an analysis of the literature allowed us to reveal the following significant differences: firstly, sustainable development is oriented towards a long-term perspective on the basis of a single strategic planning and end-to-end management process; secondly, corporate social responsibility presupposes the fulfillment of certain social and environmental responsibilities, and sustainable development is aimed at ensuring economic, environmental and social effects. In a word, the goals of these processes are different [13-15].

The concept of sustainable development of social responsibility of business received significant development and addition in the 21 st century. We emphasize that the ideas of sustainable development nowadays have received practical implementation: more and more enterprises all over the world are introducing the principles of sustainable development into business processes [16-18]. At the same time, the principles of sustainable development are beginning to be implemented not only in the activities of large industrial corporations, but in small and medium-sized businesses as well [19-21]. 
Currently, the idea of sustainable development has been embodied in a mechanism that comprehensively combines management, economic, social and environmental components for industrial corporations including metallurgical ones (Fig. 1).

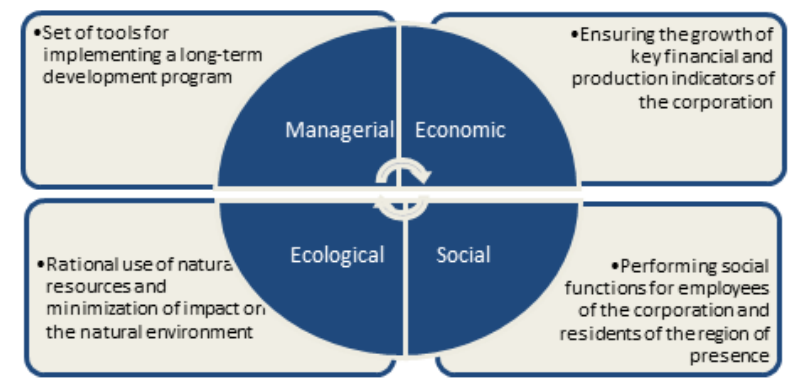

Fig. 1. The components of an integrated mechanism for sustainable development of industrial corporations

These components of the sustainable development mechanism complement each other in a complex manner. The result is a synergistic effect that enhances the influence of each individual factor on the achievement of the overall result.

The mechanism of sustainable development is formed when the following conditions are met:

- firstly, industrial corporations follow the concept of sustainable development, which is the adoption of a corporate strategy, targeting, motivating enterprises that make up a corporation, etc ;

- secondly, there is a transformation of production and business processes in order to meet the requirements of sustainable development;

- thirdly, the system of disclosure of information in the field of sustainable development, which includes economic, social and environmental indicators, which is mandatory for all enterprises of the corporation is developed and adopted.

Within the framework of the concept of economic systems sustainability, taking into account the industry specifics, the authors suggest that the sustainable development of a metallurgical corporation is understood as the development process of the mining and metallurgical enterprises, based on a common strategic planning and management and providing systematic improvement of economic, social and environmental indicators.

\subsection{Experience of disclosure of information in the field of sustainable development by metallurgical corporations}

Metallurgical corporations having industrial assets in the Russian Federation use the international standard proposed by the Global Reporting Initiative - GRI in their sustainability reports. GRI Standards are based on a Triple Bottom Line, disclosing information about the achievement of specific economic, social and environmental results. Sustainable development indicators are combined into three thematic standards: economic standard -6 indices, environmental standard -8 indices and social standard -19 ones.

The authors have compiled the list of indicators on the basis of which metallurgical corporations assess the sustainability of their development (Table 2). 
Table 2. List of indicators of sustainable development of metallurgical corporations.

\begin{tabular}{|c|c|c|c|c|c|}
\hline $\begin{array}{c}\text { Element } \\
\text { GRI }\end{array}$ & Index GRI Standards & $\begin{array}{c}\text { EVRAZ } \\
\text { Group }\end{array}$ & $\begin{array}{l}\text { Severstal } \\
\text { PJSC }\end{array}$ & $\begin{array}{l}\text { NLMK } \\
\text { Group }\end{array}$ & Metalloinvest \\
\hline \multicolumn{6}{|c|}{ Economic Standards } \\
\hline 201 & Economic Performance & $\sqrt{ }$ & $\sqrt{ }$ & $\sqrt{ }$ & $\sqrt{ }$ \\
\hline 202 & Market Presence & $\sqrt{ }$ & $\sqrt{ }$ & & $\sqrt{ }$ \\
\hline 203 & Indirect Economic Impacts & $\sqrt{ }$ & $\sqrt{ }$ & $\sqrt{ }$ & $\sqrt{ }$ \\
\hline 204 & Procurement Practices & & $\sqrt{ }$ & & $\sqrt{ }$ \\
\hline 205 & Anti-corruption & $\sqrt{ }$ & $\sqrt{ }$ & $\sqrt{ }$ & $\sqrt{ }$ \\
\hline 206 & Anti-competitive Behavior & & $\sqrt{ }$ & & \\
\hline \multicolumn{6}{|c|}{ Environmental Standards } \\
\hline 301 & Materials & & $\sqrt{ }$ & & $\sqrt{ }$ \\
\hline 302 & Energy & $\sqrt{ }$ & $\sqrt{ }$ & $\sqrt{ }$ & $\sqrt{ }$ \\
\hline 303 & Water and Effluents & $\sqrt{ }$ & $\sqrt{ }$ & $\sqrt{ }$ & $\sqrt{ }$ \\
\hline 304 & Biodiversity & $\sqrt{ }$ & $\sqrt{ }$ & $\sqrt{ }$ & $\sqrt{ }$ \\
\hline 305 & Emissions & $\sqrt{ }$ & $\sqrt{ }$ & $\sqrt{ }$ & $\sqrt{ }$ \\
\hline 306 & Waste & $\sqrt{ }$ & $\sqrt{ }$ & $\sqrt{ }$ & $\sqrt{ }$ \\
\hline 307 & Environmental Compliance & $\sqrt{ }$ & $\sqrt{ }$ & $\sqrt{ }$ & $\sqrt{ }$ \\
\hline 308 & $\begin{array}{l}\text { Supplier Environmental } \\
\text { Assessment }\end{array}$ & $\sqrt{ }$ & $\sqrt{ }$ & $\sqrt{ }$ & \\
\hline \multicolumn{6}{|c|}{ Social Standards } \\
\hline 401 & Employment & $\sqrt{ }$ & $\sqrt{ }$ & $\sqrt{ }$ & $\sqrt{ }$ \\
\hline 402 & Labor/Management Relations & & $\sqrt{ }$ & & \\
\hline 403 & $\begin{array}{l}\text { Occupational Health and } \\
\text { Safety }\end{array}$ & $\sqrt{ }$ & $\sqrt{ }$ & $\sqrt{ }$ & $\sqrt{ }$ \\
\hline 404 & Training and Education & $\sqrt{ }$ & $\sqrt{ }$ & $\sqrt{ }$ & $\sqrt{ }$ \\
\hline 405 & $\begin{array}{l}\text { Diversity and Equal } \\
\text { Opportunity }\end{array}$ & & $\sqrt{ }$ & $\sqrt{ }$ & \\
\hline 406 & Non-discrimination & & $\sqrt{ }$ & $\sqrt{ }$ & \\
\hline 407 & $\begin{array}{l}\text { Freedom of Association and } \\
\text { Collective Bargaining }\end{array}$ & & $\sqrt{ }$ & $\sqrt{ }$ & \\
\hline 408 & Child Labor & & $\sqrt{ }$ & $\sqrt{ }$ & $\sqrt{ }$ \\
\hline 409 & Forced or Compulsory Labor & & $\sqrt{ }$ & $\sqrt{ }$ & $\sqrt{ }$ \\
\hline 410 & Security Practices & & $\sqrt{ }$ & & \\
\hline 411 & Rights of Indigenous Peoples & & $\sqrt{ }$ & & \\
\hline 412 & Human Rights Assessment & & $\sqrt{ }$ & & \\
\hline 413 & Local Communities & $\sqrt{ }$ & $\sqrt{ }$ & $\sqrt{ }$ & $\sqrt{ }$ \\
\hline 414 & Supplier Social Assessment & & & & \\
\hline 415 & Public Policy & & $\sqrt{ }$ & & \\
\hline 416 & Customer Health and Safety & & $\sqrt{ }$ & & \\
\hline 417 & Marketing and Labeling & & $\sqrt{ }$ & & \\
\hline 418 & Customer Privacy & & $\sqrt{ }$ & & \\
\hline 419 & Socioeconomic Compliance & & $\sqrt{ }$ & & \\
\hline
\end{tabular}

The consolidated list revealed the following: despite the fact that all the corporations we have considered use the GRI Standards as a methodological basis for reporting, the management of each of them independently determines the number and composition of indicators of the three thematic standards. Corporations report on the environmental standard most fully: Severstal PJSC includes all indicators in the its report, other corporations exclude one indicator, and use the rest ones. The economic standard has been used quite fully: Severstal PJSC uses all 6 indicators; Metalloinvest - 5, EVRAZ Group - 4, NLMK Group - 3. The social standard, which includes the largest set of indices (19), is used selectively by corporations: Severstal PJSC uses 18 indicators, NLMK Group - 9, Metalloinvest - 6, EVRAZ Group - 4. As a result, the "Triple Bottom Line" for corporations is based on the evaluating of completely different sets of indices.

We believe that the lack of a unified methodology for disclosing information in the field of achieving sustainable development results in metallurgical corporations does not allow making their comparison. As a result the different set of indicators gives a completely different view of the non-financial activities of corporations. One of the basic principles of scientific research - the principle of comparability of results is violated. In addition, the set of indices may vary depending on the opinion of corporate management. This will prevent 
the full use of annual assessments to determine the temporal dynamics of corporation's activities in the field of sustainable development.

\section{Conclusions}

1. Nowadays the ideas of sustainable development have been put into practice: more and more enterprises all over the world are introducing the principles of sustainable development into business processes. For industrial enterprises, including metallurgical corporations, the idea of sustainable development has been embodied in a mechanism that comprehensively combines managerial, economic, social and environmental components.

2. Several largest metallurgical corporations Severstal PJSC, Metalloinvest, EVRAZ Group, NLMK Group, which have industrial facilities in Russia, have begun to apply the GRI Standards recommendations in their sustainability reports since 2018. The management of each corporation determines the number and composition of indicators for three thematic standards based on their own ideas concerning the need to include them in a sustainable development report. As a result, the "Triple Bottom Line" for corporations is formed on the basis of the assessment of a completely different set of indices.

3. The research have shown that the lack of a unified methodology for disclosing information in the field of achieving sustainable development results among metallurgical corporations does not allow making their comparison. As a result the different set of indicators gives a completely different view of the non-financial activities of corporations. One of the basic principles of scientific research - the principle of comparability of results is violated. In addition, the set of indices may vary depending on the opinion of corporate management. This will not allow full use of annual assessments to determine the temporal dynamics of corporate performance in the field of sustainable development.

4. To eliminate this shortcoming, the methodology of information disclosure in the field of sustainable development needs to be improved. We propose to use all 33 GRI Standards indices to form the Triple Bottom Line. This will eliminate inconsistencies in results. That will make it possible to track the indicators of sustainable development of corporations over time, as well as compare corporations with each other. The extension of the methodology to corporations of other types of activities will eliminate sectoral, spatial and other restrictions when comparing the results of sustainable development.

\section{Acknowledgements}

The research was supported by the Russian Science Foundation, project No. 19-18-00025.

\section{References}

1. P.A. Minakir, O.M. Prokapalo, Econ. and Soc. Chan.: Facts, Trends, Forecast, 10, 6 (2017)

2. E.G. Zinovyeva, S.V. Koptyakova, CIS Iron and Steel Rev., 17 (2019)

3. S. Baranov, T. Skufina, V. Samarina, Advanced Science Letters, 24, 9, (2018)

4. V.P. Samarina, Water Resour., 34, 5 (2007)

5. V.P. Samarina. Geochem. Intern. 46, 9 (2008)

6. T. Tambovceva, M. Tereshina, V. Samarina, 18th Inter. Scien. Conf. «Engineering for Rural Development», Proceed., 18 (2019)

7. K. Sumit, M. Nigel, J. of Clean. Prod., 84, (2014) 
8. Ch. Wang, L. Wang, S. Dai, Clean. Prod. Mag., 194, (2018)

9. C. Zhang, X. Ao, W. Kai, Z. Jiang, H. Zhang, Clean. Prod. J., 2391, (2019)

10. Global Reporting Initiative. URL: https://www.globalreporting.org/

11. H.R. Bowen Social Responsibilities of the Businessman (1953)

12. M. Friedman, The N.Y. Times Mag., 9, 13 (1970)

13. M. Maletic, D. Maletic, J. J. Dahlgaard, S. M. Dahlgaard-Park, B. Gomiscek, J. Clean. Prod., 79, (2014)

14. S. Lo, Corp. Soc. Respon. and Envir. Man., 17, 6 (2010)

15. H. Rjiba, A. Jahmane, I., Fin. Res. Let., 35 (2020)

16. K. Maas, S. Schaltegger, N., J. of Clean. Prod., 133 (2016)

17. M. Aike, J. D. Donovan, C. Topple, E. K. Masli, Clean. Prod. Mag., 216 (2019)

18. L. Suopajärvi, G.A. Poelzer, T. Ejdemo, E. Klyuchnikova, E. Korchak, V. Nygaard, Res. Pol., 47 (2016)

19. S.B. Moore, S.L. Manring, J. of Clean. Prod., 17, (2009)

20. N. Tomsic, S. Bojnec, J. of Clean. Prod., 108 (2015)

21. T. Skufina, E. Bazhutova, V. Samarina, N. Serova, Humanities \& Social Sciences Reviews, 7, 6 (2019) 